\title{
COMPARISON OF MEAN YIELD COMPONENTS AND FIBER QUALITY PARAMETERS OF ADVANCED BULK GENERATIONS IN F2, F3 AND F4 INTERSPECIFIC AND INTRASPECIFIC COTTON POPULATIONS
}

\author{
Huseyin BASAL ${ }^{1^{*}}$, Burcu DEMIROK ${ }^{2}$, Tunay KARAHAN ${ }^{3}$, Emre ILKER ${ }^{4}$, Huseyin GUNGOR \\ ${ }^{1}$ Adnan Menderes University, Faculty of Agriculture, Department of Field Crops, Aydin, TURKEY \\ ${ }^{2}$ Product Manager, Timac Agro, Istanbul, TURKEY \\ ${ }^{3}$ Product Manager, Kütaş Agro, Izmir, TURKEY \\ ${ }^{4}$ Ege University, Faculty of Agriculture, Department of Field Crops, Izmir, TURKEY \\ ${ }^{5}$ University of Düzce, Faculty of Agriculture and Natural Sciences, Department of Field Crops, \\ Duzce, TURKEY \\ *Corresponding author: hbasal@adu.edu.tr
}

Received: 23.11.2016

\begin{abstract}
The performance of interspecific and intraspecific cotton hybrid populations were compared to investigate the correlation among $F_{2}, F_{3}$ and $F_{4}$ bulk generations in terms of yield, lint percentage, and fiber quality during 2009 to 2011. In addition to that, this research investigated the effect of combining abilities on hybrid performance at further generations. For this purpose, nine interspecific and six intraspecific hybrids with eight parents were evaluated under west part of Turkey (Aegean region) environmental conditions. With the generation progresses, the highest drop in fiber length and fiber strength was detected in interspecific duo to the inbreeding depression and genetic breakdown in advanced populations. Based on 15 tested hybrids, the observed mean yield and fiber quality in the $F_{2}$ does not adequately predict the performance of hybrids in the $F_{4}$ generation. Thus, selection of individual plants should be delayed until the $F_{4}$ generation especially for interspecific hybrids, but individual plants would be selected at early generation in intraspecific hybrid populations. In the study it was found that a higher general combining ability (GCA) does not necessarily confer a higher specific combining ability (SCA) and that the GCA and SCA were independent of one another, and that in $\mathrm{F}_{4}$ high yielded hybrid population was obtained from cross which at least one parent of hybrid has maximum positive GCA effects. These results show that instead of use only one criteria, $F_{2}$ performance for intraspecific hybrids and $F_{3}$ performance for interspecific hybrids, low heterosis and inbreeding depression, combining ability of parents could be used together to determine the most promising hybrid populations to be used as a source for further selection.
\end{abstract}

Key words: Bulk generations, cotton, fiber quality, line $\mathrm{x}$ tester method

\section{INTRODUCTION}

To meet the demand of new spinning and weaving technologies in the textile industry, the major aim of cotton breeders is to develop high yield cultivars of upland cotton with improved fiber quality, especially fiber strength, fiber length, fiber length and uniformity without sacrificing yield potential. However, previous studies report that the negative association resulting from the linkage connections and pleiotropic effects between lint yield and fiber quality has hampered the simultaneous improvement of these two important characteristics in cotton (Worley et al., 1976; Green and Culp, 1990; Basal and Smith, 1997; Smith and Coyle, 1997).

The success of breeding programs depends on magnitude of genetic variation in the segregating population. The accepted general opinion is the narrowed genetic base in commercial cotton cultivars of $G$. hirsutum. The narrowed genetic base in Upland cotton cultivars is believed to be the cause for the limited success in breakup of the negative associations between lint yield and fiber quality (Zeng, 2009). May et al. (1995) point out that a narrow gene base may result in a decline in longterm genetic gains in lint yield and fiber quality. In order to increase the genetic base and to improve fiber properties of upland cotton, breeders have been trying to bring different approaches including interspecific crossing and backcrossing between Upland and Pima cotton (Zhang et al., 2016), using Acala cotton as a parent (Zhang et al., 2005), the development of a backcross inbred line (BIL) population and its use in quantitative trait locus (QTL) mapping (Yu et al., 2013), and the chromosome substitution lines (Saha et al., 2011). Introgression of useful alleles for fiber quality from $G$. 
barbadense to $G$. hirsutum has been used by plant breeders to enhance fiber length and strength in $G$. hirsutum cultivars by using conventional breeding (Ashokkumar et al., 2014). Yet, previous studies have investigated that negative correlation between yield components and fiber quality parameters, genetic breakdown in advanced populations, infertility, cytological abnormalities, distorted segregation, instability, selective elimination of desirable genes during selfing and high level of epistasis are the most important difficulties introgressing desirable alleles from $G$. barbadense into G. hirsutum, (Beasley and Brown, 1942; Kohel et al., 1977; Percival et al., 1999; GalanopoulouSendouca and Roupakias, 1999; Saha et al., 2004; Paterson et al., 2004; Basbag and Gencer, 2007; Saha et al., 2010; Zhang et al., 2014). Therefore many breeders avoid using interspecific crosses, because they typically result in reduced yield and poor agronomic qualities. Despite all the difficulties, some previous studies reached successful introgression of traits from $G$. barbadense into G. hirsutum (Culp, 1979; Culp and Harrell, 1974; Berger et al., 2011).

Most of the previous studies have been focused on the performance of the $F_{1}$, or $F_{2}$ populations and estimation of general and specific combining ability, and heterosis and inbreeding depression of hybrids in $\mathrm{F}_{1}$ and $\mathrm{F}_{2}$ generations. The correlation among the performance of hybrids in $F_{2}$, $F_{3}$, and $F_{4}$ bulk generations has not been studied to establish a consistent relation among three generations. Therefore, the objectives of this study were to investigate the correlation among the mean yield, lint percentage, and fiber quality traits of bulk generations in $F_{2}, F_{3}$, and $F_{4}$, and to determine the effect of combining abilities on hybrid performance at further generations.

\section{MATERIALS AND METHODS}

The genetic population was developed by crossing five cotton varieties (female/lines), including 'Askabat 100', 'Aydin 110', 'Sealand 542', 'GW Teks', and 'TAM94L-25', with three cotton varieties (male/tester), including 'Carmen', 'Sahin-2000', and 'SG-125', in a line× tester mating design. Askabat 100 is a Gossypium barbadense L. variety with extra long stable and finest fiber characteristics. Sealand 542 and Aydin-110 were developed through interspecific hybridization (Gossypium hirsutum L. $\times$ Gossypium barbadense L.) and have long stable and finest fiber characteristics. GW Teks ( $G$. hirsutum L.) has fiber superior strength. TAM 94L-25 (G.hirsutum L.) is an early-fruiting upland cotton line that has superior fiber length and strength even under dryland conditions (Smith, 2003). Carmen, Sahin-2000, GW Teks, and SG-125 (G. hirsutum L.) have acceptable fiber properties with high yield potential and are well-adapted current commercial cotton varieties.
Five female (lines) and three male (testers) cotton varieties were hand crossed using the line $\times$ tester method in 2006. The parents and their intraspecific and interspecific $F_{1}$ cotton populations were grown in 2007 in the experimental fields of Adnan Menderes University (ADU) Agriculture Faculty. Single lock descendant method was used to establish $\mathrm{F}_{2}, \mathrm{~F}_{3}$, and $\mathrm{F}_{4}$ generations, which were subsequently planted at ADU in 2009, 2010, and 2011, respectively. In $2009\left(\mathrm{~F}_{2}\right)$, and $2010\left(\mathrm{~F}_{3}\right)$, the 15 $\mathrm{F}_{4}$ progenies together with the eight parents were planted in a single $6 \mathrm{~m}$ long row in a randomized complete block design (RCBD) with four replications. In 2011, $\mathrm{F}_{4}$ generation the same test using the same experimental design with three replications was grown in the same location. During the experiment, seeds were sown directly to the field in May, and crop management followed the local recommendations. The distances between and within the rows were $0.70 \mathrm{~m}$ and $0.20 \mathrm{~m}$, respectively. At crop maturity, 25 well developed open bolls were hand harvested randomly from each row of parents and $F_{2}$ 's, $\mathrm{F}_{3}$ 's, and $\mathrm{F}_{4}$ 's. The bulked bolls from each genotype were ginned on a laboratory roller gin. Lint percentage (LP) was obtained from each boll sample. A high volume instrument (HVI) was used to measure upper half mean fiber length (UHML), fiber strength (FS), and micronaire (Mic.). Individual plots were then hand harvested for determination of the seed cotton weight which was converted to seed cotton yield (SCY).

All the recorded data were subjected to analysis of variance (ANOVA) techniques using MSTATC computer software separately for all the traits to evaluate statistical differences among $\mathrm{F}_{2}, \mathrm{~F}_{3}, \mathrm{~F}_{4}$ and their parental lines. The genotypes means for each parameter were further separated and compared by using the least significant difference (LSD) test at $5 \%$ level of $\mathrm{F}_{2}, \mathrm{~F}_{3}$, and $\mathrm{F}_{4}$ hybrids, respectively. The general combining ability (GCA) of parents and specific combining ability (SCA) of hybrids were estimated using line $\times$ tester analyses method described by Kempthorne (1957).

\section{RESULTS AND DISCUSSION}

Analyses of variance for the $\mathrm{F}_{2}$ and $\mathrm{F}_{3}$ generations are shown in Table 1 for seed cotton yield, lint percentage, and fiber quality parameters. Significant variations were detected among parents and hybrids for all investigated traits at the both generations. These data indicate that the parents or crosses do not follow the same pattern for investigated traits. Therefore, further analyses were performed to estimate combining abilities of parents and crosses for investigated traits in this study. In $\mathrm{F}_{2}$ generation the GCA variances were higher than SCA for UHML, STR and micronaire, and in $\mathrm{F}_{3}$ generation, the GCA variances were also greater than SCA for all the characters, indicating predominance of additive gene action in the inheritance of investigated traits. 
Table 1. Analysis of variance for yield, lint percentage, and fiber quality parameters of eight parents and 15 hybrids in $F_{2}$ and $F_{3}$ Generations

\begin{tabular}{|c|c|c|c|c|c|c|}
\hline Source of variation & df & UHML $^{1}$ & FS & Mic & $\mathbf{L P}$ & SCY \\
\hline & \multicolumn{6}{|c|}{$\mathrm{F}_{2}$} \\
\hline Replication & 3 & $3,29 *$ & 0,22 & $0,23 *$ & 1,47 & 2744,6 \\
\hline Genotypes & 22 & $8,48 * *$ & $25,16^{* *}$ & $0,53 * *$ & $28,74 * *$ & $32976,1 * *$ \\
\hline Parents & 7 & $10,03 * *$ & $30,99 * *$ & $0,76^{* *}$ & $57,33 * *$ & $14620,2 * *$ \\
\hline Parents vs. Hybrids & 1 & 30,06 & $7,39 *$ & $1,40^{* *}$ & $35,53 * *$ & $21512,6^{* *}$ \\
\hline Hybrids & 14 & $6,16^{* *}$ & $23,51 * *$ & $0,34 * *$ & $13,95 * *$ & $42972,8 * *$ \\
\hline Lines & 4 & $18,36 * *$ & $41,28 * *$ & $0,63^{* *}$ & $40,58 * *$ & $92928,0 * *$ \\
\hline Testers & 2 & 0,36 & $58,63 * *$ & 0,08 & 2,23 & $14365,8 * *$ \\
\hline Lines $\times$ Testers & 8 & 1,52 & $5,84 * *$ & $0,27 * *$ & $3,57 * *$ & $25146,9 * *$ \\
\hline Error & 66 & 1,11 & 1,21 & 0,07 & 1,10 & $1685,5^{* *}$ \\
\hline$\sigma^{2} \mathrm{GCA}$ & & 0.201 & 1,74 & 0.05 & 0,47 & 1.096 \\
\hline$\sigma^{2} \mathrm{SCA}$ & & 0.103 & 1,16 & 0.01 & 0,62 & 5.865 \\
\hline \multirow[t]{2}{*}{$\sigma^{2} \mathrm{GCA} / \sigma^{2} \mathrm{SCA}$} & & 1.95 & 1.47 & 0.05 & 0.76 & 0.19 \\
\hline & \multicolumn{6}{|c|}{$\mathrm{F}_{3}$} \\
\hline Replication & 3 & 0,16 & 2,47 & 0,06 & 1,20 & $1815,1^{*}$ \\
\hline Genotypes & 22 & $6,16 * *$ & $19,41 * *$ & $0,23 * *$ & $20,00 * *$ & $14898,5^{* *}$ \\
\hline Parents & 7 & $8,99 * *$ & $29,18 * *$ & $0,41 * *$ & $42,35 * *$ & $24641,8 * *$ \\
\hline Parents vs. Hybrids & 1 & $3,60 *$ & $29,32 * *$ & $0,48 *$ & 6,37 & $14282,6^{* *}$ \\
\hline Hybrids & 14 & $4,93 * *$ & $13,81 * *$ & 0,12 & $9,79 * *$ & $10070,9 * *$ \\
\hline Lines & 4 & $15,09 * *$ & $19,28 * *$ & 0,19 & $27,54 * *$ & $30009,2 * *$ \\
\hline Testers & 2 & 0,95 & $45,07 * *$ & 0,12 & 3,79 & $8359,7 * *$ \\
\hline Lines $\times$ Testers & 8 & 0,84 & 3,270 & 0,08 & 2,42 & 529,56 \\
\hline Error & 66 & 0,64 & 1,40 & 0,09 & 3,74 & 393,44 \\
\hline$\sigma^{2} \mathrm{GCA}^{2}$ & & 0,18 & 1,21 & 0,001 & 0,37 & 5.24 \\
\hline$\sigma^{2} \mathrm{SCA}$ & & 0,05 & 0,47 & $-0,002$ & $-0,33$ & 3.4 \\
\hline$\sigma^{2} \mathrm{GCA} / \sigma^{2} \mathrm{SCA}$ & & 3.6 & 2.57 & -0.5 & -1.12 & 1.54 \\
\hline
\end{tabular}

1 UHM: Upper half mean fiber length; FS: Fiber bundle strength; Mic.: Micronaire; LP: Lint percent; SCY: Seed cotton yield.

$*$, ** Significant at 0.05 and $0.01 \%$ levels, respectively. $2 \sigma^{2}$ GCA: general combining ability variance; $\sigma^{2}$ SCA: specific combining ability variance

\section{General and specific combining ability}

Askabat 100 ( $G$. barbadense L.) had the highest and positive GCA effects for fiber length and fiber strength, and desirable the lowest and negative GCA effects for micronaire, however same genotype had the lowest and negative GCA effects for lint percentage and yield in the two generations. It was found interesting that Aydin 110 and, Sealand 542 (G. barbadense L. x G. hirsutum L.) showed the negative GCA effects for fiber quality traits, but had the positive GCA effects for seed cotton yield in both generations. Among G. hirsitum L. varieties, GW Teks and Sahin 2000 had negative GCA effects for fiber length and fiber strength respectively, while Carmen had higher and positive GCA effects for fiber strength. TAM94L 25 and SG 125 had the highest and positive GCA effect for yield in $\mathrm{F}_{2}$ and $\mathrm{F}_{3}$ generations. None of the genotypes had consistent and higher GCA for both yield and fiber quality traits (Table 2). The results indicate that GCA of parents is largely determined by genotype performance.

For fiber length, Askabat $100 \times$ Sahin 2000 as an interspecific hybrid had positive SCA effects in $F_{2}$ and $F_{3}$.
In terms of intraspecific hybrid, TAM94L 25 x Carmen and GW Teks $\mathrm{x}$ Carmen were found as best specific combiners by having maximum SCA effects in $F_{2}$ and $F_{3}$, respectively. Askabat 100 x Sahin 2000 and Sealand 542 x Carmen in $\mathrm{F}_{2}$ generation, and Aydin 110 x SG 125 hybrid in $\mathrm{F}_{3}$ generation revealed positive and significant SCA effects for fiber strength. Askabat $100 \times$ x S 125 and GW Teks x Carmen had desirable negative SCA effects for micronaire in $\mathrm{F}_{2}$ generation. For fiber percentage, the highest SCA effect owned by Sealand 542 x Sahin 2000 in $F_{2}$, and by GW Teks $x$ Sahin 2000 in $F_{3}$. Majority of interspecific hybrids in both generations exhibited negative SCA effects for yield, while Askabat $100 \mathrm{x}$ Carmen, Aydin 110 x Sahin 2000, and Sealand 542 x SG 125 hybrids showed positive and significant SCA effects for yield in $\mathrm{F}_{2}$ generation (Table 3). In $\mathrm{F}_{2}$ generation, $\mathrm{GW}$ Teks x SG 125 and TAM94L 25 x Carmen revealed positive and significant SCA effects for seed cotton yield. None of the inter and intraspecific hybrids had positive and significant SCA effects for seed cotton yield in $\mathrm{F}_{3}$ generation (Table 3). 
Table 2. General combining ability effects of lines and testers for yield, lint percentage, and fiber quality parameters in $F_{2}$ and $F_{3}$ generations.

\begin{tabular}{|c|c|c|c|c|c|}
\hline & \multicolumn{5}{|c|}{$F_{2}$ generation } \\
\hline & UHML $^{1}$ & FS & Mic & $\mathbf{L P}$ & SCY \\
\hline \multicolumn{6}{|l|}{ Lines } \\
\hline Askabat 100 & $2,16^{* *}$ & $2,98^{* *}$ & $-0,411^{* *}$ & $-1,47 * *$ & $-150,5^{* *}$ \\
\hline Aydin 110 & $-0,44$ & 0,05 & 0,152 & $0,67 *$ & $30,3^{*}$ \\
\hline Sealand 542 & $-0,34$ & $-2,05 * *$ & 0,063 & $-1,35 * *$ & $79,6 * *$ \\
\hline GW Teks & $-0,99 * *$ & $-0,21$ & 0,087 & $2,92 * *$ & 9,3 \\
\hline TAM94L 25 & $-0,39$ & $-0,77 *$ & 0,112 & $-0,77 * *$ & $31,3 *$ \\
\hline S.E. Lines & 0,304 & 0,318 & 0,075 & 0,302 & 9,18 \\
\hline \multicolumn{6}{|l|}{ Tester } \\
\hline Carmen & 0,16 & $1,86^{* *}$ & $-0,013$ & 0,13 & $-23,5$ \\
\hline Sahin 2000 & $-0,08$ & $-1,52 * *$ & $-0,061$ & $-0,38$ & $-5,6$ \\
\hline SG 125 & $-0,07$ & $-0,34$ & 0,072 & 0,25 & $29,2 * *$ \\
\hline \multirow[t]{3}{*}{ S.E. Testers } & 0,235 & 0,246 & 0,058 & 0,234 & 11,85 \\
\hline & \multicolumn{5}{|c|}{$F_{3}$ generation } \\
\hline & UHML $^{1}$ & FS & Mic & $\mathbf{L P}$ & SCY \\
\hline \multicolumn{6}{|l|}{ Lines } \\
\hline Askabat 100 & $1,75^{* *}$ & $1,74^{* *}$ & $-0,132$ & $-0,87$ & $-85,1 * *$ \\
\hline Aydin 110 & $-0,72 * *$ & $-0,58$ & 0,134 & 0,40 & $14,5^{*}$ \\
\hline Sealand 542 & $-0,44$ & $-1,69 * *$ & 0,043 & $-1,95 * *$ & $18,3 * *$ \\
\hline GW Teks & $-1,03 * *$ & 0,06 & 0,091 & $2,09 * *$ & 5,4 \\
\hline TAM94L 25 & 0,44 & 0,47 & $-0,130$ & 0,33 & $46,9 * *$ \\
\hline S.E. Lines & 0,23 & 0,34 & 0,09 & 0,56 & 5,73 \\
\hline \multicolumn{6}{|l|}{ Tester } \\
\hline Carmen & 0,24 & $1,57 * *$ & 0,022 & $-0,38$ & $-2,9$ \\
\hline Sahin 2000 & $-0,16$ & $-1,42 * *$ & $-0,091$ & $-0,09$ & $-18,9 * *$ \\
\hline SG 125 & $-0,08$ & $-0,16$ & 0,073 & 0,47 & $21,7 * *$ \\
\hline S.E. Testers & 0,18 & 0,26 & 0,07 & 0,43 & 4,43 \\
\hline
\end{tabular}

1 UHM: Upper half mean fiber length; FS: Fiber bundle strength; Mic.: Micronaire; LP: Lint percent; SCY: Seed cotton yield.

\section{Parent and Hybrid Performance}

The results for parents and hybrids performance tested in three years are shown in Table 4 and 5. The eight parents used in this study varied significantly for each of the evaluated yield components and fiber quality parameters. Based on three years mean, as expected the longest fibers were produced by Askabat 100 (32,9 mm) (G. barbadense L.), followed by Aydin-110 (32,2 mm) and Sealand $542(31,0 \mathrm{~mm})$ which were developed through interspecific hybridization. Among the upland cotton parents, fiber length varied from $29.0 \mathrm{~mm}$ (Carmen) to $30.1 \mathrm{~mm}$ (TAM94L 25). Askabat 100 had the strongest fiber $\left(35.7 \mathrm{cN}\right.$ tex $\left.^{-1}\right)$ followed by Aydin 110 (35.5 cN tex $\left.{ }^{-1}\right)$, TAM94L 25 (34.0 cN tex $\left.{ }^{-1}\right), \mathrm{GW}$ Teks $\left(33.9 \mathrm{cN} \mathrm{tex}^{-1}\right)$, and Carmen $\left(33.7 \mathrm{cN}\right.$ tex $\left.{ }^{-1}\right)$, and Sahin2000 had the weakest fiber strength $\left(28.7 \mathrm{cN} \mathrm{tex}^{-1}\right)$. The lowest micronaire was detected in Askabat 100 (3.9 Mic.), and the investigated trait was ranged from 4.9 Mic. (Carmen) to 4.3 Mic. (Aydin 110) among the rest of the cotton genotypes (Table 4). In terms of mean lint percentage, SG 125 and Sealand 542 had maximum (42.0 $\%)$ and minimum (34.0\%) lint percentages, respectively (Table 5). The highest mean seed cotton yield of $3857 \mathrm{~kg}$ $\mathrm{h}^{-1}$ was obtained in TAM94L 25 and was followed by Sahin $2000\left(3844 \mathrm{~kg} \mathrm{~h}^{-1}\right)$, SG 125 (3799 $\left.\mathrm{kg} \mathrm{h}^{-1}\right)$ and Carmen $\left(3726 \mathrm{~kg} \mathrm{~h}^{-1}\right)$. The lowest mean seed cotton yield was recorded in Askabat 100 (2386 kg h$\left.{ }^{-1}\right)$ (Table 5).

In $F_{2}, F_{3}$, and $F_{4}$ generations, interspecific hybrids had distinguished fiber quality parameters including fiber length, fiber strength, and fiber fineness (Table 4). The highest fiber length was recorded for Askabat $100 \times$ Sahin 2000 hybrid at $F_{2}, F_{3}$, and $F_{4}$ generations. In $F_{2}$ and $F_{3}$, Askabat 100 x Sahin 2000 was followed by Askabat 100 x Carmen and Askabat 100 x SG 125 hybrids. Among hybrids in F4, the longest fiber length was produced by Askabat 100 x Sahin 2000 (32.1 mm) and TAM94L $25 \mathrm{x}$ Sahin $2000(31.8 \mathrm{~mm})$ hybrids and difference in fiber length between interspecific and intraspecific hybrids was not significant. 
Table 3. Specific combining ability effects of lines $x$ testers crosses for yield, lint percentage, and fiber quality parameters in $F_{2}$ and $\mathrm{F}_{3}$ generations.

\begin{tabular}{|c|c|c|c|c|c|}
\hline \multirow[b]{2}{*}{ Interspecific hybrids } & \multicolumn{5}{|c|}{$F_{2}$ generation } \\
\hline & UHML $^{1}$ & FS & Mic & LP & SCY \\
\hline Askabat 100 x Carmen & $-0,90$ & $-0,67$ & 0,10 & 0,84 & $59,1 * *$ \\
\hline Askabat 100 x Sahin 2000 & 0,99 & $1,11^{*}$ & 0,24 & 0,00 & $-13,2$ \\
\hline Askabat 100 x SG 125 & $-0,09$ & $-0,44$ & $-0,34 *$ & $-0,83$ & $-45,9 *$ \\
\hline Aydin 110 x Carmen & $-0,15$ & $-1,23 *$ & 0,08 & $-0,02$ & 19,6 \\
\hline Aydin 110 x Sahin 2000 & $-0,15$ & 0,15 & $-0,03$ & $-0,41$ & $90,2 * *$ \\
\hline Aydin 110 x SG 125 & 0,30 & 1,08 & $-0,06$ & 0,43 & $-109,6^{* *}$ \\
\hline Sealand 542 x Carmen & 0,29 & $1,53 * *$ & 0,15 & $-0,68$ & $-72,2 * *$ \\
\hline Sealand 542 x Sahin 2000 & $-0,05$ & $-1,50 * *$ & $-0,07$ & $1,20 *$ & $-11,1$ \\
\hline Sealand 542 x SG 125 & $-0,24$ & $-0,03$ & $-0,07$ & $-0,53$ & $83,3 * *$ \\
\hline \multicolumn{6}{|l|}{ Intraspecific hybrids } \\
\hline GW Teks x Carmen & 0,04 & 0,87 & $-0,38 *$ & $-0,97$ & $-50,4^{*}$ \\
\hline GW Teks x Sahin 2000 & $-0,30$ & 0,24 & 0,05 & 0,16 & $-2,6$ \\
\hline GW Teks x SG 125 & 0,26 & $-1,11^{*}$ & $0,33^{*}$ & 0,81 & $53,0 *$ \\
\hline TAM94L 25x Carmen & 0,72 & $-0,50$ & 0,05 & 0,82 & $44,0^{*}$ \\
\hline TAM94L 25x Sahin 2000 & $-0,48$ & 0,00 & $-0,19$ & $-0,95$ & $-63,4 * *$ \\
\hline TAM94L 25x SG 125 & $-0,24$ & 0,50 & 0,14 & 0,12 & 19,4 \\
\hline \multirow[t]{2}{*}{ S.E. } & 0,53 & 0,55 & 0,13 & 0,52 & 20,53 \\
\hline & \multicolumn{5}{|c|}{$F_{3}$ generation } \\
\hline Interspecific hybrids & UHML $^{1}$ & FS & Mic & LP & SCY \\
\hline Askabat 100 x Carmen & $-0,05$ & $-0,25$ & 0,11 & 0,56 & $-7,42$ \\
\hline Askabat 100 x Sahin 2000 & 0,53 & 0,17 & $-0,17$ & $-0,30$ & $-3,63$ \\
\hline Askabat 100 x SG 125 & $-0,47$ & 0,08 & 0,06 & $-0,27$ & 11,04 \\
\hline Aydin 110 x Carmen & 0,02 & $-0,51$ & 0,08 & 0,69 & $-1,00$ \\
\hline Aydin 110 x Sahin 2000 & $-0,55$ & $-0,77$ & 0,11 & 0,00 & $-3,55$ \\
\hline Aydin 110 x SG 125 & 0,52 & $1,27 *$ & $-0,18$ & $-0,69$ & 4,55 \\
\hline Sealand 542 x Carmen & $-0,30$ & $-0,80$ & 0,06 & $-0,26$ & 9,04 \\
\hline Sealand 542 x Sahin 2000 & 0,28 & 0,79 & $-0,10$ & $-0,35$ & 5,18 \\
\hline Sealand 542 x SG 125 & 0,01 & 0,01 & 0,04 & 0,61 & $-14,22$ \\
\hline \multicolumn{6}{|l|}{ Intraspecific hybrids } \\
\hline GW Teks x Carmen & 0,35 & 1,04 & $-0,12$ & $-0,20$ & 2,78 \\
\hline GW Teks x Sahin 2000 & $-0,46$ & $-0,52$ & 0,07 & 0,84 & $-11,64$ \\
\hline GW Teks x SG 125 & 0,11 & $-0,51$ & 0,05 & $-0,65$ & 8,86 \\
\hline TAM94L 25 x Carmen & $-0,03$ & 0,52 & $-0,13$ & $-0,80$ & $-3,40$ \\
\hline TAM94L 25 x Sahin 2000 & 0,21 & 0,33 & 0,09 & $-0,21$ & 13,63 \\
\hline TAM94L $25 \times$ SG 125 & $-0,18$ & $-0,85$ & 0,04 & 1,00 & $-10,23$ \\
\hline S.E. & 0,40 & 0,59 & 0,15 & 0,97 & 9,92 \\
\hline
\end{tabular}

1 UHM: Upper half mean fiber length; FS: Fiber bundle strength; Mic.: Micronaire; LP: Lint percent; SCY: Seed cotton yield.

Comparison of performance of $\mathrm{F}_{4}$ with $\mathrm{F}_{2}$ and $\mathrm{F}_{3}$ generations showed that the hybrids in which Askabat 100 was used as a female parent revealed considerable reduction in fiber length. Declining trend in fiber length was higher at interspecific hybrids than that of intraspecific hybrids. In another research, genetic breakdown has been reported to be prevalent in later generations of interspecific hybrids (Percival et al. 1999) (Table 4). While there were no significant differences in fiber length between Askabat $100 \mathrm{x}$ Carmen and Askabat 100 x Sahin 2000 in $F_{1}$ (Basal et al. 2009), fiber length of former hybrid was lower than that of later hybrid due to the high inbreeding depression $(-9.43 \%)$ in $\mathrm{F}_{2}$ generation. Therefore, Askabat $100 \times$ Carmen exhibited a trend of fiber length decrease from generation to generation, while Askabat 100 x Sahin 2000 reached stability in terms of fiber length in $F_{3}$ generation. These results indicate that relatively small inbreeding depression in $\mathrm{F}_{2}$ would be used a good indicator to determine the most appropriate hybrid population to be used as a source population for further selection which is consistent with previous studies (Meredith, 1990; Yuan et al., 2002, Khan et al., 2007, Galanopoulou and Roupakias, 1999; Khan et al., 2010).

Among the crosses having longest fiber length in $\mathrm{F}_{4}$, Askabat 100 x Sahin $2000(32.1 \mathrm{~mm})$ showed positive, Askabat 100 x SG 125 (31.1 mm) exhibited negative SCA effects in $F_{2}$ and $F_{3}$ generations. In $F_{4}$ intraspecific hybrids, maximum fiber length was obtained in the cross combination TAM94L-25 x Sahin 2000 (31.8 mm). TAM94L-25 x Sahin 2000 had negative SCA effects in $F_{2}$ and positive SCA effects for fiber length in $\mathrm{F}_{3}$ generation (Table 3). Among parents involving these hybrids, only Askabat 100 had high and positive GCA effect for fiber length (Table 2). Therefore, high $\mathrm{x}$ low and low $\mathrm{x}$ low 
general combiners revealed promising SCA for fiber length. The present study confirms that good combination for improved fiber quality may not always obtained from parents with positive GCA effects, sometimes parents with low GCA could produce high fiber length. The results indicated that a higher GCA does not necessarily confer a higher SCA and that the GCA and SCA were independent of one another a finding similar to the results of Khan et al. (2007), Basal et al. (2009), and Baloch et al. (2016). On the other hand, Coyle and Smith (1997), Hassan et al. (2000) and Khan et al. (2009) reported that parents with high GCA were found to produce high yielding hybrids.

Table 4. Mean fiber length, fiber strength, and micronaire of crosses and parents at $F_{2}, F_{3}$, and $F_{4}$ generations.

\begin{tabular}{|c|c|c|c|c|c|c|c|c|c|}
\hline \multirow[b]{2}{*}{ Interspecific hybrids } & \multicolumn{3}{|c|}{$\begin{array}{c}\text { Upper half mean fiber length } \\
(\mathrm{mm})\end{array}$} & \multicolumn{3}{|c|}{$\begin{array}{c}\text { Fiber strength } \\
\left.(\mathrm{cN} \mathrm{tex})^{-1}\right)\end{array}$} & \multicolumn{3}{|c|}{$\begin{array}{l}\text { Micronaire } \\
\text { (unit) }\end{array}$} \\
\hline & $\mathbf{F}_{2}$ & $\mathbf{F}_{3}$ & $\mathbf{F}_{4}$ & $\mathbf{F}_{2}$ & $\mathbf{F}_{3}$ & $\mathbf{F}_{4}$ & $\mathbf{F}_{2}$ & $\mathbf{F}_{3}$ & $\mathbf{F}_{4}$ \\
\hline Askabat 100 x Carmen & $32,5 b c$ & $32,6 a b$ & $29.9 \mathrm{e}-\mathrm{i}$ & $37,3 a$ & $35,5 \mathrm{bc}$ & $34.1 \mathrm{a}-\mathrm{d}$ & $4,0 \mathrm{gh}$ & $4,3 a-f$ & $4.8 \mathrm{e}-1$ \\
\hline Askabat 100 x Sahin 2000 & $34,2 \mathrm{a}$ & $32,8 \mathrm{ab}$ & $32.1 \mathrm{a}-\mathrm{c}$ & $35,7 b$ & $32,9 d-f$ & $34.2 \mathrm{a}-\mathrm{d}$ & $4,1 \mathrm{fg}$ & $3,9 \mathrm{fg}$ & $4.2 \mathrm{mn}$ \\
\hline Askabat 100 x SG 125 & $33,0 \mathrm{ab}$ & $31,9 b c$ & $31.1 \mathrm{a}-\mathrm{g}$ & $35,3 b c$ & $34,1 b-d$ & $31.2 \mathrm{f}-1$ & $3,7 \mathrm{i}$ & $4,3 \mathrm{a}-\mathrm{f}$ & $4.9 b-1$ \\
\hline Aydin 110 x Carmen & $30,6 \mathrm{e}-\mathrm{i}$ & $30,2 d-i$ & $30.1 \mathrm{~d}-\mathrm{i}$ & $33,8 \mathrm{c}-\mathrm{f}$ & $32,9 d-f$ & $32.4 \mathrm{c}-\mathrm{k}$ & $4,5 b-e$ & $4,5 \mathrm{ab}$ & $4.9 \mathrm{a}-\mathrm{k}$ \\
\hline Aydin 110 x Sahin 2000 & $30,4 d-h$ & $29,4 \mathrm{ii}$ & $30.0 \mathrm{~d}-\mathrm{i}$ & $31,8 \mathrm{~g}-\mathrm{i}$ & $29,7 \mathrm{i}$ & $30.9 \mathrm{~h}-1$ & $4,4 d-f$ & $4,4 a-d$ & $5.1 \mathrm{a}-\mathrm{f}$ \\
\hline Aydin 110 x SG 125 & $30,8 d-f$ & $30,4 d-h$ & $30.4 c-h$ & $33,9 c-f$ & $33,0 d-f$ & $30.5 \mathrm{i}-1$ & $4,5 c-e$ & $4,5 \mathrm{a}-\mathrm{c}$ & $5.0 \mathrm{a}-\mathrm{k}$ \\
\hline Sealand 542 x Carmen & $31,1 \mathrm{c}-\mathrm{f}$ & $30,2 \mathrm{e}-\mathrm{i}$ & 29.2hi & $34,4 b-e$ & $31, \mathrm{f}-\mathrm{i}$ & $30.0 \mathrm{kl}$ & $4,5 b-e$ & $4,4 a-d$ & $5.3 a-d$ \\
\hline Sealand 542 x Sahin 2000 & $30,6 \mathrm{~d}-\mathrm{g}$ & $30,3 d-h$ & $29.8 \mathrm{f}-\mathrm{i}$ & $28,0 \mathrm{j}$ & $30,1 \mathrm{~h}-\mathrm{i}$ & $30.3 \mathrm{j}-1$ & $4,3 e-g$ & $4,1 \mathrm{~b}-\mathrm{g}$ & $5.1 \mathrm{a}-\mathrm{g}$ \\
\hline Sealand 542 x SG 125 & $30,4 d-h$ & $30,2 \mathrm{e}-\mathrm{i}$ & $30.9 a-h$ & $30,7 \mathrm{ii}$ & $30,6 \mathrm{~g}-\mathrm{i}$ & $32.1 \mathrm{~d}-1$ & $4,4 d-g$ & $4,4 a-d$ & $4.9 \mathrm{a}-\mathrm{k}$ \\
\hline \multicolumn{10}{|l|}{ Intraspecific hybrids } \\
\hline GW Teks x Carmen & $30,2 d-h$ & $30,2 d-i$ & $30.3 c-h$ & $35,6 b$ & $35,1 b c$ & $33.7 a-e$ & $4,0 \mathrm{gh}$ & $4,3 \mathrm{a}-\mathrm{f}$ & $4.8 \mathrm{~d}-1$ \\
\hline GW Teks x Sahin 2000 & $29,7 \mathrm{f}-\mathrm{i}$ & $29,0 \mathrm{i}$ & $30.5 c-h$ & 31,6hi & $30,5 \mathrm{~g}-\mathrm{i}$ & $31.0 \mathrm{~g}-1$ & $4,4 \mathrm{~d}-\mathrm{f}$ & 4,3a-e & $4.9 \mathrm{a}-\mathrm{k}$ \\
\hline GW Teks x SG 125 & $30,2 \mathrm{~d}-\mathrm{i}$ & $29,7 \mathrm{~g}-\mathrm{i}$ & $29.8 d-i$ & $31,4 \mathrm{hi}$ & $31,8 \mathrm{f}-\mathrm{h}$ & $32.6 \mathrm{c}-\mathrm{j}$ & $4,8 \mathrm{a}-\mathrm{c}$ & $4,5 \mathrm{a}-\mathrm{c}$ & $5.2 \mathrm{a}-\mathrm{e}$ \\
\hline TAM94L 25 x Carmen & $31,5 \mathrm{c}-\mathrm{e}$ & $31,3 \mathrm{~cd}$ & $30.0 \mathrm{~d}-\mathrm{i}$ & $33,7 d-f$ & $35,0 \mathrm{bc}$ & $32.6 \mathrm{c}-\mathrm{j}$ & $4,5 b-e$ & $4,0 \mathrm{~d}-\mathrm{g}$ & $4.7 \mathrm{e}-1$ \\
\hline TAM94L 25 x Sahin 2000 & $30,1 \mathrm{~d}-\mathrm{i}$ & $31,1 \mathrm{c}-\mathrm{e}$ & $31.8 \mathrm{a}-\mathrm{e}$ & $30,8 \mathrm{i}$ & $31,8 \mathrm{f}-\mathrm{h}$ & $31.9 \mathrm{~d}-1$ & $4,2 \mathrm{e}-\mathrm{g}$ & $4,1 \mathrm{~b}-\mathrm{g}$ & $4.6 \mathrm{~g}-\mathrm{m}$ \\
\hline TAM94L 25 x SG 125 & $30,3 \mathrm{~d}-\mathrm{h}$ & $30,8 \mathrm{c}-\mathrm{f}$ & $29.9 f-i$ & $32,5 \mathrm{f}-\mathrm{g}$ & $31,9 \mathrm{f}-\mathrm{h}$ & $31.9 \mathrm{~d}-1$ & $4,6 b-d$ & $4,2 \mathrm{a}-\mathrm{f}$ & $5.3 \mathrm{a}-\mathrm{c}$ \\
\hline \multicolumn{10}{|l|}{ Lines } \\
\hline Askabat 100 & $32,6 b c$ & $33,7 a$ & $32.5 \mathrm{ab}$ & $35,1 b-d$ & $37,5 \mathrm{a}$ & $34.6 a-c$ & 3,7hi & $3,9 \mathrm{e}-\mathrm{g}$ & $3.9 n$ \\
\hline Aydin 110 & $31,6 b-d$ & $32,7 \mathrm{ab}$ & $32.3 \mathrm{ab}$ & $35,8 \mathrm{ab}$ & $35,3 \mathrm{bc}$ & $35.3 \mathrm{ab}$ & $4,5 \mathrm{~d}-\mathrm{f}$ & $3,8 \mathrm{~g}$ & $4.6 \mathrm{k}-\mathrm{m}$ \\
\hline Sealand 542 & $29,8 f-i$ & $31,7 \mathrm{bc}$ & $31.4 \mathrm{a}-\mathrm{f}$ & $30,7 \mathrm{i}$ & $32,1 \mathrm{e}-\mathrm{g}$ & $31.1 f-1$ & $4,5 \mathrm{c}-\mathrm{e}$ & $3,7 \mathrm{~g}$ & $4.8 c-1$ \\
\hline GW Teks & $28,9 \mathrm{~h}-\mathrm{i}$ & $30,0 f-i$ & $30.2 \mathrm{~d}-\mathrm{h}$ & $32,4 \mathrm{f}-\mathrm{h}$ & $33,8 \mathrm{c}-\mathrm{e}$ & $35.6 \mathrm{a}$ & $4,4 d-f$ & $4,1 \mathrm{~b}-\mathrm{g}$ & $4.6 \mathrm{j}-\mathrm{m}$ \\
\hline TAM94L 25 & $30,1 \mathrm{e}-\mathrm{i}$ & $30,2 \mathrm{e}-\mathrm{i}$ & $30.1 \mathrm{~d}-\mathrm{h}$ & $34,9 \mathrm{~b}-\mathrm{e}$ & $34,0 b-d$ & $33.2 \mathrm{a}-\mathrm{h}$ & $5,0 \mathrm{a}$ & $4,5 \mathrm{a}-\mathrm{c}$ & $4.7 \mathrm{e}-\mathrm{m}$ \\
\hline \multicolumn{10}{|l|}{ Testers } \\
\hline Carmen & $27,9 \mathrm{i}$ & $30,8 \mathrm{c}-\mathrm{g}$ & $28.2 \mathrm{i}$ & $33,3 \mathrm{e}-\mathrm{g}$ & $35,8 \mathrm{ab}$ & $31.9 d-1$ & $5,0 \mathrm{a}$ & $4,3 \mathrm{a}-\mathrm{e}$ & $5.5 \mathrm{a}$ \\
\hline Sahin 2000 & $28,7 \mathrm{i}$ & $29,4 h-i$ & $29.8 \mathrm{f}-\mathrm{i}$ & $28,6 \mathrm{j}$ & $29,0 \mathrm{i}$ & 29.71 & $4,9 \mathrm{ab}$ & $4,1 \mathrm{c}-\mathrm{g}$ & $4.9 b-1$ \\
\hline SG 125 & $29,1 \mathrm{i}$ & $30,1 \mathrm{e}-\mathrm{i}$ & $29.3 \mathrm{~g}-\mathrm{i}$ & $29,1 \mathrm{ij}$ & $31,3 \mathrm{f}-\mathrm{i}$ & $31.1 \mathrm{f}-1$ & $4,8 \mathrm{ab}$ & $4,6 \mathrm{a}$ & $5.3 \mathrm{ab}$ \\
\hline $\mathrm{LSD}_{0.05}$ & 1.53 & 1.12 & 1.86 & 1.59 & 1.88 & 2.20 & 0.35 & 0.43 & 0.50 \\
\hline
\end{tabular}

Based on three generation means, the highest fiber strength value was obtained from Askabat $100 \times$ Carmen (35.6 cN tex-1) and GW Teks x Carmen (34.3 $\mathrm{cN}$ tex-1) crosses among hybrids, respectively (Table 4). When the mean performance of hybrids in F4 was compared with previous generations, four out of 15 hybrids exhibited decreased fiber strength and the highest reduction in fiber strength was observed in interspecific hybrids especially for Askabat $100 \times$ SG 125. The decrease in fiber strength with the increasing in homozygosity at further generations would be due to the dominant $\mathrm{x}$ dominant epistatic gene effect or parents with negative homozygote dominant gene effect for investigated trait. Wu et al. (2010) observed that inbreeding depression in several crosses would be expected in later generations if parents had negative homozygous dominance effects for a trait.

In case of fiber strength, Askabat $100 \times$ Carmen and Askabat 100 x Sahin 2000 interspecific hybrids and GW
Teks x Carmen intraspecific hybrid produced the strongest fibers throughout generations. Line Askabat 100 and tester Carmen showed maximum positive GCA effects and excelled other parental cultivars for fiber strength. Tester Sahin 2000 had the highest negative GCA effects (Table 2). The result show that parents with high and positive GCA were able to produce increased fiber strength at further generation as reported by previous Coyle and Smith (1997), Hassan et al. (2000) and Khan et al. (2009). Askabat 100 x Sahin 2000 and Sealand542 x Carmen in $\mathrm{F}_{2}$, and in $\mathrm{F}_{3}$ Aydin 110 x SG 125 exhibited positive SCA effects for investigated fiber trait (Table 3 ). Based on the performance of these hybrids, high $\mathrm{x}$ low, low $\mathrm{x}$ high and low $x$ low GCA parents were involved in presentation of highest desirable SCA for fiber strength.

Fiber fineness (micronaire) values between 3.7 and 4.2 are optimum for yarn spinning; therefore, negative GCA is desirable for fiber fineness, since a coarser fiber (higher 
than 4.2 micronaire) negatively affects the spinning process, as well as overall quality. For investigated trait, the lines GCA ranged from -0.411 to 0.152 in $\mathrm{F}_{2}$, and from -0.132 to 0.134 in $F_{3}$, while in testers the GCA ranged from -0.061 to 0.072 in $\mathrm{F}_{2}$, and from -0.091to 0.073 in $F_{3}$ (Table 2). Generally, fiber fineness of all hybrids progressively increased from $\mathrm{F}_{2}$ to $\mathrm{F}_{4}$ generation due to the additive gene effect (Table 4). In F4 generation, among 15 hybrids, the most fineness fiber was observed in Askabat 100 x Sahin 2000 hybrid population, and both parents have negative GCA for fineness. These result shows that parents with good GCA would produce appropriate hybrid population for selection.

Generally G. hirsutum L. cultivars and intraspecific hybrids had higher lint percentage than developed through interspecific hybridization $(G$. hirsutum L. $\times G$. barbadense L.) cultivars and $G$. barbadense L. cultivars, and interspecific hybrids (Table 5). Majority of hybrids exhibited a trend of increased lint percentage from $F_{2}$ to $F_{4}$ that may be attributable to the involvement of additive genes via increasing homozygosity. In $\mathrm{F}_{4}$, among interspecific and intraspecific hybrids maximum lint percentage was recorded in Aydin 110 x Sahin 2000 and GW Teks x Carmen, respectively. At least one parent of those hybrids showed maximum positive GCA effects and excelled other parental cultivars (Table 2). Aydin $110 \mathrm{x}$ Sahin 2000 exhibited negative SCA effects in $F_{2}$, and GW Teks $x$ Carmen revealed negative SCA effects in $\mathrm{F}_{2}$ and $\mathrm{F}_{3}$ generations (Table 3). The result showed that the GCA and SCA were independent of one another a finding similar to the results of Khan et al. (2007) and Basal et al. (2009). On the other hand, the present study confirms that good combination for improved lint percentage would be obtained from parents with positive GCA effects. Also Coyle and Smith (1997) and Lukonge et al. (2008) reported that parents with high GCA were found to produce high yielding hybrids.

The three years mean seed cotton yield performances of parents are presented in Table 5. Among the eight parents, as expected the lowest yield was obtained from Askabat 100 (2386 kg ha-1), and TAM94L 25 reached the highest yield $\left(3857 \mathrm{~kg} \mathrm{ha}^{-1}\right)$. In $\mathrm{F}_{4}$ generation, the seed cotton yield varied from $1960 \mathrm{~kg} \mathrm{ha}^{-1}$ (Askabat $100 \times$ SG 125) to $3467 \mathrm{~kg} \mathrm{ha}^{-1}$ (Aydin $110 \mathrm{x} \mathrm{SG}$ 125) among the interspecific hybrids, $3114 \mathrm{~kg} \mathrm{ha}^{-1}$ (GW Teks x Carmen) to $3634 \mathrm{~kg} \mathrm{ha}^{-1}$ (GW Teks x Sahin 2000) among the intraspecific hybrids. The hybrids did not follow same pattern in terms of responses to progressive generations (in subsequent generations). The low yielded hybrids in $\mathrm{F}_{2}$ exhibited a fairly high yield in $\mathrm{F}_{4}$ or vice versa due to the over dominance and inbreeding depression, and also some of the high yielded hybrids in $\mathrm{F}_{2}$ generation tended to yield more in the subsequent generations. Our results indicated that the performance of the $\mathrm{F}_{4}$ hybrids would not be adequately estimated by the performance of the $F_{2}$ hybrid (Table 5). Similarly, Meredith and Bridge (1973) found no significant correlation between the $\mathrm{F}_{2}$ and $\mathrm{F}_{3}$ mean yields in ten $G$. hirsutum L. hybrids. Also, Galanopoulou-Sendouca and Roupakias, (1999) reported that the yield of the $F_{1}$ did not predict the yield of the bulks in the following generations.

In $\mathrm{F}_{4}$ generation among the inter- and intraspecific hybrids, the highest seed cotton yield was obtained from Aydin 110xSG 125 (3467 kg ha ${ }^{-1}$ ) and GW Teks x Sahin 2000 (3634 kg ha-1) crosses, respectively (Table 5) even after segregation and inbreeding depression. Aydin $110 \mathrm{x}$ SG 125 had negative SCA effects in $F_{2}$ and positive SCA effects for investigated trait in $\mathrm{F}_{3}$ generation (Table 3). Both parents of Aydin 110xSG 125 had high and positive GCA effect for yield (Table 2). GW Teks x Sahin 2000 had negative SCA effects in both generations (Table 3). GW Teks exhibited positive; Sahin 2000 had negative GCA for seed cotton yield (Table 2). Therefore, high $\mathrm{x}$ high and low $\mathrm{x}$ low general combiners revealed promising SCA for seed cotton yield. Singh et al. (2010) reported that most of the hybrids were among the crosses of good $\times$ poor, average $\times$ poor and poor $\times$ poor general combiner parents for seed cotton yield which indicated the involvement of additive, complementary and non- additive gene actions, respectively for such characters. If the hybrid having two poor general combiner parents express higher SCA effects that means dominant genes were involved in the manifestation of SCA effects and when two good general combiners express higher SCA effects that may be attributable to the involvement of additive genes (Ahuja and Dhayal 2007; Singh et al., 2010). The present study confirms that good combination for high seed cotton yield may not always obtained from parents with positive GCA effects, sometimes parents with low and negative GCA could produce high seed cotton yield. The results indicated that a higher GCA does not necessarily confer a higher SCA and that the GCA and SCA were independent of one another a finding similar to the results of Khan et al. (2007), Basal et al. (2009) and Baloch et al. (2016). Present study showed that that parents with high GCA were found to produce high yielding hybrids which is consistent with previous studies (Coyle and Smith 1997; Hassan et al. 2000; Lukonge et al. 2007, and Khan et al. 2009) 
Table 5. Mean lint percentage and seed cotton yield of crosses and parents at $F_{2}, F_{3}$, and $F_{4}$ generations.

\begin{tabular}{|c|c|c|c|c|c|c|}
\hline \multirow[b]{2}{*}{ Interspecific hybrids } & \multicolumn{3}{|c|}{$\begin{array}{c}\text { Lint percentage } \\
(\%)\end{array}$} & \multicolumn{3}{|c|}{$\begin{array}{l}\text { Seed cotton yield } \\
\left(\mathrm{kg} \mathrm{ha}^{-1}\right)\end{array}$} \\
\hline & $\begin{array}{l}F_{2} \\
2009\end{array}$ & $\begin{array}{l}F_{3} \\
2010\end{array}$ & $\begin{array}{l}F_{4} \\
2011\end{array}$ & $\begin{array}{l}\mathbf{F}_{2} \\
2009\end{array}$ & $\begin{array}{l}\mathbf{F}_{3} \\
2010\end{array}$ & $\begin{array}{l}F_{4} \\
2011\end{array}$ \\
\hline Askabat 100 x Carmen & $36,2 \mathrm{~h}-\mathrm{k}$ & $37,5 \mathrm{c}-\mathrm{g}$ & $38.9 \mathrm{~b}-\mathrm{g}$ & $2312 \mathrm{k}$ & $2037 j$ & $1778 \mathrm{j}$ \\
\hline Askabat 100 x Sahin 2000 & $34,9 \mathrm{i}-1$ & $36,9 \mathrm{e}-\mathrm{g}$ & $36.8 \mathrm{~d}-\mathrm{g}$ & 17731 & $1912 j$ & $3039 c-h$ \\
\hline Askabat 100 x SG 125 & $34,7 \mathrm{j}-1$ & $37,5 \mathrm{c}-\mathrm{g}$ & $39.1 \mathrm{~b}-\mathrm{g}$ & 17911 & $2467 \mathrm{hi}$ & $1960 \mathrm{ij}$ \\
\hline Aydin 110 x Carmen & $37,5 \mathrm{e}-\mathrm{i}$ & $38,9 a-e$ & $39.6 b-g$ & $3727 f g$ & 3096df & $3052 \mathrm{c}-\mathrm{g}$ \\
\hline Aydin 110 x Sahin 2000 & $36,6 \mathrm{~g}-\mathrm{j}$ & $38,5 b-f$ & $40.9 \mathrm{a}-\mathrm{e}$ & $4614 b c$ & $2910 f g$ & $3252 b-e$ \\
\hline Aydin 110 x SG 125 & $38,1 \mathrm{e}-\mathrm{h}$ & $38,4 \mathrm{~b}-\mathrm{g}$ & $40.6 a-e$ & $2966 \mathrm{ij}$ & $3397 \mathrm{bc}$ & $3467 a-e$ \\
\hline Sealand 542 x Carmen & $34,8 \mathrm{j}-1$ & $35,6 \mathrm{gh}$ & $38.6 b-g$ & 3305hi & $3234 \mathrm{ce}$ & $2660 e-j$ \\
\hline Sealand 542 x Sahin 2000 & $36,2 \mathrm{~h}-\mathrm{k}$ & $35,8 \mathrm{f}-\mathrm{h}$ & $37.4 \mathrm{~d}-\mathrm{g}$ & $4095 \mathrm{df}$ & $3035 \mathrm{ef}$ & $2853 \mathrm{~d}-\mathrm{i}$ \\
\hline Sealand 542 x SG 125 & $35,1 \mathrm{i}-1$ & $37,3 \mathrm{c}-\mathrm{g}$ & $36.9 \mathrm{~d}-\mathrm{g}$ & $5380 \mathrm{a}$ & 3247 ce & $3145 b-f$ \\
\hline \multicolumn{7}{|l|}{ Intraspecific hybrids } \\
\hline GW Teks x Carmen & $38,8 \mathrm{c}-\mathrm{f}$ & $39,7 a-d$ & $43.4 \mathrm{ab}$ & $2811 \mathrm{ij}$ & $3043 \mathrm{ef}$ & $3114 c-g$ \\
\hline GW Teks x Sahin 2000 & $39,4 b-e$ & $41,0 \mathrm{ab}$ & $40.6 a-e$ & $3477 \mathrm{gh}$ & $2739 \mathrm{gh}$ & $3634 a-d$ \\
\hline GW Teks x SG 125 & $40,7 a-c$ & $40,1 \mathrm{a}-\mathrm{c}$ & $40.5 \mathrm{a}-\mathrm{f}$ & $4380 \mathrm{~b}$ & $3350 \mathrm{bd}$ & $3169 b-e$ \\
\hline TAM94L 25 x Carmen & $36,9 f-i$ & $37,3 \mathrm{c}-\mathrm{g}$ & $39.4 b-g$ & $3981 \mathrm{df}$ & $3396 b c$ & $3228 b-e$ \\
\hline TAM94L 25 x Sahin 2000 & $34,6 \mathrm{kl}$ & $38,2 \mathrm{~b}-\mathrm{g}$ & $35.6 \mathrm{e}-\mathrm{g}$ & $3085 \mathrm{i}$ & $3406 \mathrm{bc}$ & $3231 b-e$ \\
\hline TAM94L 25 x SG 125 & $36,0 \mathrm{i}-\mathrm{k}$ & $40,0 \mathrm{a}-\mathrm{c}$ & $37.5 \mathrm{~d}-\mathrm{g}$ & $4261 \mathrm{~cd}$ & $3574 \mathrm{~b}$ & $3523 a-e$ \\
\hline \multicolumn{7}{|l|}{ Lines } \\
\hline Askabat 100 & $37.6 \mathrm{e}-\mathrm{i}$ & $36.2 \mathrm{e}-\mathrm{h}$ & $35.3 \mathrm{fg}$ & $2601 \mathrm{jk}$ & $2330 \mathrm{i}$ & $2227 g-j$ \\
\hline Aydin 110 & $33.21 \mathrm{~m}$ & 33.7hi & $35.9 \mathrm{e}-\mathrm{g}$ & $3822 \mathrm{fg}$ & $2185 \mathrm{ij}$ & $2836 \mathrm{~d}-\mathrm{i}$ \\
\hline Sealand 542 & $31.6 n$ & $32.3 \mathrm{i}$ & $38.2 \mathrm{~b}-\mathrm{g}$ & $3859 \mathrm{ef}$ & $2847 \mathrm{fg}$ & $3212 b-e$ \\
\hline GW Teks & $42.2 \mathrm{a}$ & $39.7 \mathrm{a}-\mathrm{d}$ & $43.6 \mathrm{a}$ & 3176hi & $2907 \mathrm{fg}$ & $2845 d-i$ \\
\hline TAM94L 25 & $39.5 b-e$ & $39.9 a-c$ & $40.3 \mathrm{a}-\mathrm{f}$ & $4304 \mathrm{~cd}$ & $4061 \mathrm{a}$ & $3206 b-e$ \\
\hline \multicolumn{7}{|l|}{ Testers } \\
\hline Carmen & $40.2 \mathrm{a}-\mathrm{d}$ & 39.0a-e & $38.7 \mathrm{~b}-\mathrm{g}$ & $4036 \mathrm{df}$ & $4132 a$ & $3011 \mathrm{c}-\mathrm{h}$ \\
\hline Sahin 2000 & $38.5 \mathrm{~d}-\mathrm{g}$ & $38.7 b-f$ & $41.8 \mathrm{a}-\mathrm{d}$ & $4279 \mathrm{~cd}$ & $3955 a$ & 3298b-e \\
\hline SG 125 & $41.4 \mathrm{ab}$ & $41.6 \mathrm{a}$ & $42.9 \mathrm{a}-\mathrm{c}$ & 4208de & $3594 b$ & $3595 a-d$ \\
\hline LSD $_{0.05}$ & 2.015 & 2.875 & 5.28 & 370.4 & 280.4 & 903.4 \\
\hline
\end{tabular}




\section{CONCLUSIONS}

With the generation progresses, the highest drop in fiber length and fiber strength was detected in interspecific hybrids in which Askabat 100 was used as a female parent. The abrupt drop for fiber length and fiber strength in further generation was due to the inbreeding depression. Among the interspecific hybrids Askabat 100 $\mathrm{x}$ Sahin 2000 had less inbreeding depression in $\mathrm{F}_{2}$ and also from the $F_{3}$ onwards had stabilized fiber length. Therefore, a relatively small inbreeding depression in the $\mathrm{F}_{2}$ would be used as a selection criterion to determine promising hybrid populations to be used as source for further selection. The observed mean yield and fiber quality in the $F_{2}$ does not adequately predict the performance of hybrids in the $\mathrm{F}_{4}$ generation. Duo to the genetic distance among parents used in interspecific crosses, genetic breakdown in advanced populations, distorted segregation, and high level of epistasis interspecific hybrids had the lowest stability level. Therefore, selection of individual plants should be delayed until the $\mathrm{F}_{4}$ generation for interspecific hybrids, but individual plants would be selected at early generation in intraspecific hybrid populations. The present study confirms that in $\mathrm{F}_{4}$ generation high yielded hybrid population had at least one parent having high GCA for investigated traits. These results show that instead of use only one criteria, $F_{2}$ performance for intraspecific and $F_{3}$ performance for interspecific hybrids, low inbreeding depression, and combining ability of parents could be used together to determine the most promising hybrid populations to be used as source populations for further selection.

\section{LITERATURE CITED}

Ahuja, S.L. and L.S. Dhayal. 2007. Combining ability estimates for yield and fiber quality traits in $4 \times 13$ line $\times$ tester crosses of $G$. hirsutum. Euphytica. 153:87-98.

Ashokkumar, K. K.S. Kumar, and R. Ravikesavan. 2014. An update on conventional and molecular breeding approaches for improving fiber quality traits in cotton. African Journal of Biotechnology. Vol. 13:1097-1108.

Baloch, M.J., Q.A. Bughio1, A.W. Baloch, W.A. Jatoi, M.A. Arain, A. Baloch and F.M. Halo. 2016. Evaluation of Genetic Potential of Intrahirsutum F2 Populations Through Line $\times$ Tester Analysis. The Journal of Animal \& Plant Sciences. 26:745-753.

Basal, H., A. Unay, O. Canavar and I. Yavas. 2009. Combining ability for fibre quality parameters and within-boll yield components in intraspecific and interspecific cotton populations. Span J Agric Res. 7:364-374.

Basal, H. and C.W. Smith. 1997. The association of fiber quality parameters and lint yield components in F3 derived F4 progeny of two upland cotton populations. Proc. Beltwide Cotton Prod. Res. Conf. Memphis, TN., Vol. 1, pp. 478-479.

Basbag, S. and O. Gencer. 2007. Investigation of some yield and fibre quality characteristics of interspecific hybrid (Gossypium hirsutum L. x G. barbadense L.) cotton varieties. Hereditas: 144:33-42.

Beasley, J.O. and M.S. Brown. 1942. Asynaptic Gossypium plants and their polyploids. J. Agric. Res. 65:421-427.

Berger G., S.H. Hague, C. Hague, C.W. Smith, P.S. Thaxton, and D.C. Jones. 2011. Development of sea island/upland
(SIUP) germplasm with unique fiber properties. The Journal of Cotton Science: 15:260-264.

Coyle, G.G. and C.W. Smith. 1997. Combining ability for within-boll yield components in cotton, $G$. hirsutum L. Crop Sci. 37:1118-1122.

Culp, T.W. and D.C. Harrell. 1974. Breeding quality cotton at the PEE DEE experiment station Florence, S.C. USDA ARS-S-30, New Orleans, LA.

Culp, T.W. 1979. Notice to plant breeders and geneticists relative to release of five Noncommercial breeding stocks of extra-long staple Upland cotton, Sealand 542, Earlistaple 7, Line F (Hybrid 330), FJA, and FTA. S.C. Agric. Exp. Stn Bull.

Galanopoulou-Sendouca, S. and G. Roupakias. 1999. Performance of cotton F1 hybrids and its relation to the mean yield of advanced bulk generations. European J. Agron. 11:53-62.

Green, C.C. and T.W. Culp. 1990. Simultaneous improvement of yield, fiber quality, and yarn strength in upland cotton. Crop Sci. 30:66-69.

Hassan, G., G. Mahmood, A. Razzaq and Hayatullah. 2000. Combining ability in inter-varietal crosses of Upland cotton. Sarhad J. Agric. 16:407-410.

Khan, N.U., G. Hassan, M.B. Kumbhar, S. Kang, I. Khan, A. Parveen, and M. Saeed. 2007. Heterosis, inbreeding depression and mean performance of segregating population in upland cotton. European Journal of Scientific Research. 18:338-353.

Khan, N.U., H. Basal and G. Hassan. 2010. Cottonseed oil and yield assessment via economic heterosis and heritability in intra-specific cotton populations. Afr. J. Biotechnol. 9: 74187428.

Khan, N.U., G. Hassan, M.B. Kumbhar, K.B. Marwat, M.A. Khan, A. Parveen, U. Aiman and M. Saeed. 2009. Combining ability analysis to identify suitable parents for heterosis in seed cotton yield, its components and lint \% in upland cotton. Ind. Crops \& Prod. 29: 108-115.

Khempthorne, O. 1957. An introduction to genetic statistics. Wiley, New York.

Kohel, R.J., J.E. Endrizzi and T.G. White. 1977. An evaluation of Gossypium barbadense L. chromosomes 6 and 17 in theG.hirsutum L. genome. Crop Sci. 17:404-406.

Lukonge, E.P., M.T.Labuschagne, and L. Herselman. $2008 \mathrm{i}$. Combining ability for yield and fibre characteristics in Tanzanian cotton germplasm. Euphytica, 161:383-389

May, O.L., D.T. Bowman and D.S. Calhoun. 1995. Genetic diversity of US Upland cotton cultivars released between 1980 and 1990. Crop Sci. 35:1570-1574.

Meredith, W.R. and R.R. Bridge. 1973. The relationship between F2 and selected F3 progenies in cotton Gossypium hirsutum L. Crop Sci. 13:354-356.

Meredith, W.R. 1990. Yield and fiber-quality potential for secondgeneration cotton hybrids. Crop Sci. 30: 1045-1048.

Meredith, W.R. and R.R. Bridge. 1973. Therelationshipbetween F2 andselected F3 progenies in cotton (Gossypium hirsutum L.). Crop Sci. 13:354-356.

Paterson A.H., R.K. Boman, S.M. Brown, P.W. Chee, J.R. Gannaway, A.R. Gingle, O.L. May and C.W. Smith. 2004. Reducing the genetic vulnerability in cotton. Crop Sci. 44:1900-1901

Percival, A.E., J.F. Wendel, and J.M. Stewart. 1999. Taxonomy and germplasm resources. In: Cotton: Origin, History, Technology, and Production. ed. Smith, C.W. and Cothren, J.T., 33-64, Wiley and Sons, New York, NY.

Saha, S., J. Wu, J.N. Jenkins, J.C. McCarty, O.A. Jr. Gutierrez, D.M. Stelly, R.G. Percy, D.A. Raska. 2004. Effect of chromosome substitutions from GossypiumbarbadenseL.3- 
79 into G.hirsutumL. TM-1 on agronomic and fiber traits. J. Cotton Sci. 8:162-169.

Saha, S, J. Wu, J.N. Jenkins, J.C. McCarty, R. Hayes and D.M. Stelly. 2010. Genetic dissection of chromosome substitution lines discovered novel alleles in Gossypium barbadense L. with potential for improving agronomic traits including yield. Theor Appl. Genet. 120:193-1205.

Saha, S., D.M. Stelly, D.A. Raska, J. Wu, J.N. Jenkins, J.C. McCarty, A. Makamov, V. Gotmare, I.Y. Abdurakhmonov and B.T. Campbell. 2011. Chromosome substitution lines: concept, development and utilization in the genetic improvement of Upland cotton. In: Plant Breeding. ed. I.Y. Abdurakhmonov, 107-128. In Tech. Open Access Publisher, Croatia.

Singh, S., V.V. Singh and A.D. Choudhary, 2010. Combining ability estimates for oil content, yield components and fiber quality traits in cotton $(G$. hirsutum) using an $8 \times 8$ diallel mating design. Trop. Subtrop. Agroeco. 12:161-166

Smith, C.W. and G.G. Coyle. 1997. Association of fiber quality parameters and within-boll yield components in upland cotton. Crop Sci. 37:1775-1779.

Smith, C.W. 2003. Registration of TAM 94L-25 and TAM 94J-3 germplasm lines of upland cotton with improved fiber length. Crop Sci 43: 742-743.

Worley, S. Jr., H.H. Jr. Ramey, D.C. Harrell and T.W. Culp. 1976. Ontogenetic model of cotton yield. Crop Sci. 16:3034.
Wu, J., J.C. Mccarty, J.N. Jenkins and W.R. Meredit. 2010. Breeding potential of introgressions into upland cotton: genetic effects and heterosis. Plant Breeding. 129:526-532.

Yu, J., K. Zhang, S. Li, S. Yu, H. Zhai, M. Wu, X. Li, S. Fan, M. Song, D. Yang, Y. Li and J. Zhang. 2013. Mapping quantitative trait loci for lint yield and fiber quality across environments in a Gossypium hirsutum $\times$ Gossypium barbadense backcross inbred line population. Theor Appl Genet. 126:275-287.

Yuan, YL, T.Z. Zhang, W.Z. Guo, J.J. Pan, R.J. Kohel. 2002. Heterosis and gene action of boll weight and lint percentage in high quality fibre property varieties in upland cotton. Acta Agron. Sin. 28: 196-202.

Zeng, L. and W.R. Meredith, Jr. 2009. Associations among lint yield, yield components, and fiber properties in an introgressed population of cotton. Crop Sci. 49:1647-1654.

Zhang, J.F., Y. Lu, H. Adragna and E. Hughs. 2005. Genetic improvement of New Mexico Acala cotton germplasm. Crop Sci. 45:2363-2373.

Zhang J.F, R.G. Percy and J.C. McCarty. 2014. Introgression genetics and breeding between Upland and Pima cotton- a review. Euphytica. 198:1-12.

Zhang J, M. Wu, J. Yu, X. Li, W. Pei. 2016. Breeding Potential of Introgression Lines Developed from Interspecific Crossing between Upland Cotton (Gossypium hirsutum) and Gossypium barbadense: Heterosis, Combining Ability and Genetic Effects. PLoS ONE 11(1). http://journals.plos.org/plosone/article?id=10.1371/journal.p one.0143646. (Accessed November 20, 2016). 